\title{
Ectosymbiotic behavior of Cancer gracilis and its trophic relationships with its host Phacellophora camtschatica and the parasitoid Hyperia medusarum
}

\author{
Trisha Towanda*, Erik V. Thuesen
}

Laboratory I, Evergreen State College, Olympia, Washington 98505, USA

\begin{abstract}
In southern Puget Sound, large numbers of megalopae and juveniles of the brachyuran crab Cancer gracilis and the hyperiid amphipod Hyperia medusarum were found riding the scyphozoan Phacellophora camtschatica. C. gracilis megalopae numbered up to 326 individuals per medusa, instars reached 13 individuals per host and $H$. medusarum numbered up to 446 amphipods per host. Although C. gracilis megalopae and instars are not seen riding Aurelia labiata in the field, instars readily clung to $A$. labiata, as well as an artificial medusa, when confined in a planktonkreisel. In the laboratory, C. gracilis was observed to consume H. medusarum, P. camtschatica, Artemia franciscana and A. labiata. Crab fecal pellets contained mixed crustacean exoskeletons (70\%), nematocysts $(20 \%)$, and diatom frustules $(8 \%)$. Nematocysts predominated in the fecal pellets of all stages and sexes of $H$. medusarum. In stable isotope studies, the $\delta^{13} \mathrm{C}$ and $\delta^{15} \mathrm{~N}$ values for the megalopae $(-19.9$ and 11.4, respectively) fell closely in the range of those for $H$. medusarum $(-19.6$ and 12.5 , respectively) and indicate a similar trophic reliance on the host. The broad range of $\delta^{13} \mathrm{C}(-25.2$ to -19.6$)$ and $\delta^{15} \mathrm{~N}(10.9$ to 17.5$)$ values among crab instars reflects an increased diversity of diet as crabs develop. The association between $C$. gracilis and P. camtschatica is unusual because of the ontogenic switch of the symbiont from a primarily kleptoparasitic association to a facultative cleaning association. It is suggested that $P$. camtschatica incidentially concentrates $H$. medusarum in its oral arms as the symbionts transfer from its gelatinous prey. Metabolic studies suggest that by riding medusae crabs may be able to develop faster through transport into warmer surface waters while reducing the energetic costs associated with locomotion.
\end{abstract}

KEY WORDS: Symbiosis - Scyphozoa $\cdot$ Commensal crab · Hyperiid amphipod - Cleaning behavior · Stable isotope $\cdot$ Metabolic rate $\cdot$ Fecal pellet

\section{INTRODUCTION}

Planktonic cnidarians form symbiotic relationships with both vertebrates and invertebrates. Several small fishes and juveniles of larger fishes are known to live among the stinging tentacles of jellyfishes, where they find both shelter and food (Jones 1960, Noble 1963, Thiel 1970, Brodeur 1998). Symbiotic invertebrates of planktonic Cnidaria encompass a broad taxonomic spectrum, including Cnidaria, Platyhelminthes, Nematoda, Gastropoda, Cephalopoda, Echinodermata, Pycnogonida and Crustacea (Thiel 1976, Brandon \& Cutress 1985, Morton 1989, Théodoridès 1989). These organisms may profit from the mobile nature of their hosts, allowing otherwise sessile animals access to the benefits of a pelagic lifestyle. Although many kinds of crustaceans are known to associate with jellyfishes, including shrimps (Bruce 1972, Marliave \& Mills 1993), barnacles (Pagès 2000) and copepods (Browne \& Kingsford 2005), most studies of the symbiotic associations between crustaceans and gelatinous zooplankton have focused on the parasitic relationships between hyperiid amphipods and gelatinous representatives of various phyla, including Cnidaria, Ctenophora, Mollusca and Urochordata (Harbison et al. 1977, Madin \& Harbison 1977, Thurston 1977, Laval 1980, Dittrich 
1988, Sorarrain et al. 2001, Gasca \& Haddock 2004). During their early stages of development, hyperiid amphipods have been established as obligate parasites of gelatinous hosts (Harbison et al. 1977), and Hyperia medusarum Müller is one hyperiid species that remains associated through adulthood and is recognized as a marine parasitoid (Laval 1980). Although much of the life cycle of $H$. medusarum has been examined, the mechanisms of its winter survival and the dynamics of fall population outbreaks remain unclear.

The symbiotic relationships between cnidarians and brachyuran crabs are less clearly defined. Numerous symbioses of this type have been observed in the field and noted in the literature. Crabs are thought to benefit from enhanced mobility and shelter, however specific interactions in these relationships have remained largely uncharacterized.

The scyphozoan jellyfish Phacellophora camtschatica Brandt is considered to be a predator that specializes on gelatinous zooplankton prey (Strand \& Hamner 1988, Purcell 1990). It is known to host Hyperia medusarum as well as larval and juvenile stages of the crab Cancer gracilis Dana (Wrobel \& Mills 1998). C. gracilis is one of the most common benthic macroinvertebrates in southern Puget Sound, and large numbers of C. gracilis and $H$. medusarum have been found riding $P$. camtschatica in southern Puget Sound from late spring through early fall. The present study used a suite of methods to investigate trophic interactions between these 3 species to better understand the nature of their symbiotic relationships.

\section{MATERIALS AND METHODS}

Animal collection. Phacellophora camtschatica was collected from Budd Inlet and Eld Inlet in the southern most regions of Puget Sound, Washington, USA, during May through October from 1994 through 2003 during years of $P$. camtschatica outbreaks, specifically, 1994, 1996, 2001, 2002 and 2003. The medusae were hand-dipped with 201 plastic containers from small boats and docks, taking great care not to stimulate the Cancer gracilis ectosymbionts clinging to the medusae, since some megalopae will abandon the host when disturbed. Data were collected only from those jellyfish sampled without disturbance. Epizoic C. gracilis and Hyperia medusarum were enumerated, and the bell diameter of each medusa was measured with a flexible tape measure. The 1 very large specimen of P. camtschatica collected (60 cm bell diam.) was examined for epibionts and measured in situ.

Representative specimens were taken to the laboratory for experimentation and observation. Crabs and amphipods captured for fecal pellet collections were sorted by species. Cancer gracilis was further sorted into instars and megalopae. Hyperia medusarum was separated into males, females and juveniles. All specimens were rinsed with filtered seawater (FSW, $0.45 \mu \mathrm{m}, 30 \mathrm{psu}$ ) and transferred individually or in small groups $(<10)$ into $20 \mathrm{ml}$ containers before being transported to the laboratory. Specimens obtained for enzyme analyses were immediately frozen in liquid nitrogen upon return to the laboratory. Megalopae were identified to species using the key developed by DeBrosse et al. (1990). Amphipods were keyed using Bowman (1973).

Zooplankton tows to collect free-living megalopae and zoeae were conducted 3 to 5 times per week in daylight and darkness from May through September 2003. Vertical tows were made with a $0.5 \mathrm{~m}$ ring net (333 $\mu \mathrm{m})$. Instars 3' to 5' were collected from sediments in southern Puget Sound at low tide. Instar stage was determined by comparing carapace width with that of specimens reared in the laboratory (Orensanz \& Gallucci 1988).

Field observations. Field observations of behavior were conducted opportunistically while collecting specimens. Phacellophora camtschatica was observed near docks, nearshore, and in open water. Other cnidarians, ctenophores and surface flotsam were also surveyed for the presence of Cancer gracilis and Hyperia medusarum over the study period. Predation on P. camtschatica and associated ectosymbionts was photographed with a Nikon Nikonos III $35 \mathrm{~mm}$ camera. Video recordings were taken with a JVC GR-DVL9000 digital video camera.

Laboratory observations. Medusae and the megalopae and instars of Cancer gracilis were maintained together and observed in a 271 planktonkreisel with FSW $(10 \mu \mathrm{m})$ at $13^{\circ} \mathrm{C}$. Phacellophora camtschatica specimens were cleaned of amphipods and kept singly in plastic chambers and in a 271 planktonkreisel. Specimens were fed ad libitum with Artemia franciscana and Aurelia labiata, established prey species of $P$. camtschatica (Strand \& Hamner 1988). A. labiata were maintained in a 401 planktonkreisel. Instars and megalopae were observed consuming food items in the planktonkreisel and with a dissecting microscope. Numerous megalopae were reared into instars to confirm species $(\mathrm{n}>50)$. To investigate instar predation on Hyperia medusarum, instars were placed into the planktonkreisel, and an individual P. camtschatica infested with $H$. medusarum was then also introduced into the planktonkreisel to determine if crabs were preying on amphipods while residing on the host. To augment this experiment, instars were also isolated with $H$. medusarum specimens in a $100 \mathrm{ml}$ glass crystallizing dish to observe interactions between C. gracilis and $H$. medusarum with a dissecting microscope. 
Photographs were taken with an Olympus D550 digital camera. Photographs of the ectosymbionts were taken with a Leica MZ16 dissecting microscope interfaced with a motorized z-axial focusing drive, a JVC-KYF70B digital camera, and a Syncroscopy Auto-Montage software system.

Behavioral experiments. Several experiments were designed to test the hypothesis that Cancer gracilis is a species-specific epibiont of Phacellophora camtschatica. Experiments were conducted in the planktonkreisel described above; all specimens of $P$. camtschatica in planktonkreisel experiments had a bell diameter of $12 \pm 1 \mathrm{~cm}$. The questions posed were:

- Will crabs ride Aurelia labiata? Instars and megalopae of Cancer gracilis were released in a planktonkreisel with A. labiata and monitored over a period of $3 \mathrm{~d}$ to detect riding behavior

- Will epibiont crabs on Aurelia labiata switch to Phacellophora camtschatica? To test for preference, $P$. camtschatica was released into a planktonkreisel which contained instar crabs that had been riding A. labiata for $24 \mathrm{~h}$

- Will crabs ride any gelatinous object? An artificial jellyfish (pseudomedusa: Fig. 1) was constructed to mimic a non-specific gelatinous zooplankter. Pseudomedusae were composed of 2 separately molded blocks of Knox ${ }^{\mathrm{TM}}$ gelatin $(7 \mathrm{~g}), 1$ formed with $200 \mathrm{ml}$ of FSW and 1 with $200 \mathrm{ml}$ of deionized water to control orientation and buoyancy. The 2 portions were bound together with a hand-tied net of nylon cord. Hyperia medusarum and instars and megalopae of Cancer gracilis were placed in the planktonkreisel with a pseudomedusa and observed over $24 \mathrm{~h}$

- Will crabs switch from the pseudomedusa to Phacellophora camtschatica? Megalopae and instars of Cancer gracilis were placed in the planktonkreisel with a pseudomedusa. After $3 \mathrm{~h}$ when crabs were riding, a specimen of $P$. camtschatica was introduced into the planktonkreisel and observed throughout the following $4 \mathrm{~h}$.

Fecal pellet collection and analysis. Immediately after collection in the field, Hyperia medusarum and Cancer gracilis were placed separately, in groups of less than 10, into $100 \mathrm{ml}$ containers filled with FSW $(0.45 \mu \mathrm{m})$. Containers were monitored hourly for fecal pellets with a dissection microscope, which were collected and transferred to an FSW $(0.45 \mu \mathrm{m})$ solution of $3 \%$ each formaldehyde and glutaraldehyde. Fecal pellets were collected in the same manner from C. gracilis reared in the laboratory and fed exclusively with H. medusarum for $3 \mathrm{~d}$. Pellets were examined with Nomarski differential interference contrast microscopy using a Zeiss Universal microscope at $500 \times$ and $1600 \times$. Photomicrographs were taken with a Nikon 4500 digital camera. Identifiable particles were quantified through a 2-D analysis of photomicrographs by measuring the area of identifiable components in squashed fecal pellets. Identifiable components fell into 3 categories: diatoms, nematocysts and crustacean fragments. Values are reported as percentages of total identifiable components.

Stable isotope analyses. Specimens were collected as described above from Budd Inlet and Eld Inlet in southern Puget Sound and processed for stable carbon and nitrogen isotope analyses. Cheliped tissue from 1 adult female Cancer gracilis collected in a benthic trap set in Budd Inlet was also analyzed. Small specimens were pooled; larger specimens were processed either as individuals or discrete tissues. Specimens were prepared by drying at $60^{\circ} \mathrm{C}$ to constant weight, then ground using an acid-washed mortar and pestle. Samples were re-dried overnight, ground again and transferred to Eppendorf tubes. Specimens were sent to the Marine Science Institute Analytical Laboratory at the University of California, Santa Barbara, and analyzed on a Europa Tracermass isotope ratio mass spectrometer following the methods of Page (1997). Natural abundances of the stable isotopes ${ }^{13} \mathrm{C}$ and ${ }^{15} \mathrm{~N}$ are

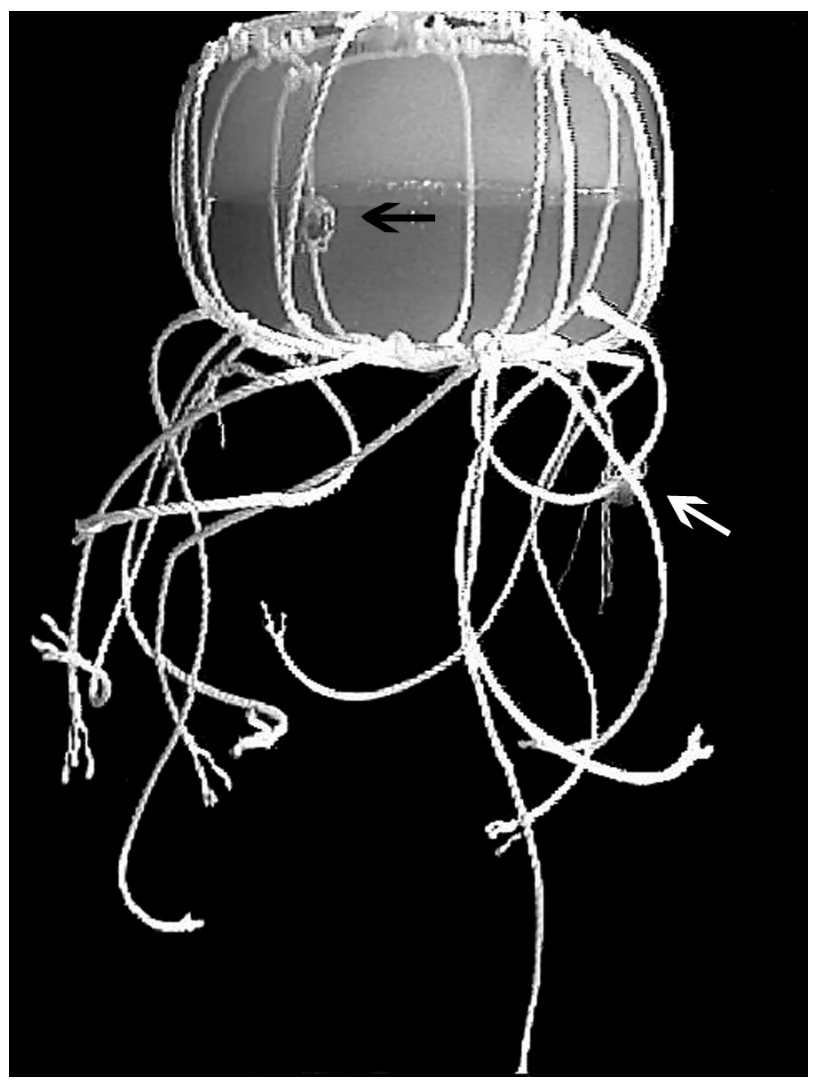

Fig. 1. Pseudomedusa - an artificial non-specific gelatinous zooplankter constructed from gelatin and nylon cord to investigate riding behavior of ectosymbiont crustaceans; 2 instars of Cancer gracilis (arrows) are visible clinging to bell and tentacles. Bell diameter $=12 \mathrm{~cm}$ 
expressed as per mil $(\delta X \%$, where $X$ is the relative abundance of the rare stable isotope of carbon and nitrogen relative to the Pee Dee Belemnite (PDB) standard and atmospheric $\mathrm{N}_{2}$, respectively; Libes 1992).

Oxygen consumption. To evaluate the metabolic effects of riding medusae, oxygen consumption rates of free-living Cancer gracilis megalopae were compared to those of instars and megalopae collected from Phacellophora camtschatica. No free-living benthic instars $1^{\prime}$ and $2^{\prime}$ could be found, so no comparisons between riding and free-living instars could be made. The oxygen consumption rates of $C$. gracilis megalopae and instars were measured at least $12 \mathrm{~h}$ but not more than $36 \mathrm{~h}$ after collection, following the procedures of Thuesen et al. (2005). Individual crabs were placed in $2 \mathrm{ml}$ glass syringes with FSW $(0.22 \mu \mathrm{m}, 30 \mathrm{psu})$ containing $100 \mathrm{mg} \mathrm{l}^{-1}$ each of streptomycin and ampicillin. The syringes were placed in a temperature-controlled, circulating water bath at $10^{\circ} \mathrm{C}$ on an orbital shaker to ensure adequate mixing and constant temperature and were kept in darkened conditions for the duration of each measurement. Oxygen concentrations were measured continuously with a Microx TX3 temperaturecompensated fiber optic oxygen meter with Type B2 oxygen micro-optodes (Precision Sensing). The probes were calibrated with $100 \%$ oxygen-saturated seawater and $0 \%$ oxygen solution of $\mathrm{Na}_{2} \mathrm{SO}_{3}$. The optode was inserted into the respiration chamber through a gastight septum. After experiments were concluded, the crabs were blotted dry and weighed on a Mettler analytical balance. Control experiments were run in respiration chambers containing the same seawater and antibiotic mixture. Energy rations were calculated based on a conversion rate of $3.25 \mathrm{cal} \mathrm{mg}^{-1} \mathrm{O}_{2}$ in poikilothermic animals consuming a mixed diet of proteins and lipids (Brett \& Groves 1979) and then converted by a factor of $4.19 \mathrm{~J} \mathrm{cal}^{-1}$ to obtain $\mathrm{kJ} \mathrm{g}^{-1}$.

Enzymatic activity. Lactate dehydrogenase (LDH, EC 1.1.1.27) and citrate synthase (CS, EC 4.1.3.7) were selected as enzymatic indicators of metabolic potential and evaluated according to the methods of Thuesen \& Childress (1994). LDH is a rate-limiting catalyst in the conversion of pyruvate to lactate during anaerobic metabolism. LDH is an indicator of glycolytic potential. $\mathrm{CS}$ is also rate-limiting and the first catalyst in the Krebs cycle, reacting with oxaloacetate and acetylcoenzyme A to form citrate. CS is an indicator of aerobic metabolic potential. Individual, frozen Cancer gracilis megalopae and instars were hand homogenized on ice in $5 \mathrm{ml}$ glass, tissue homogenizers in dilutions ranging from 1:24 to $1: 49$ parts wt vol ${ }^{-1}$ of $50 \mathrm{mmol}$ imidazole buffer, $\mathrm{pH} 7.4$ at $10^{\circ} \mathrm{C}$. Aliquots were centrifuged at $7000 \times g$ at $2{ }^{\circ} \mathrm{C}$ for $10 \mathrm{~min}$. Aliquots of the supernatants $(50 \mu l)$ were combined with the assay cocktail solutions ( $1 \mathrm{ml}$ total volume) in quartz cuvettes.
Assays were performed in a water-jacketed cuvette holder at $20^{\circ} \mathrm{C}$ on a Hewlett-Packard diode array spectrophotometer within $1 \mathrm{~h}$ of homogenization under non-limiting conditions to estimate maximum potentials.

Activities are expressed as $\mu \mathrm{mol}$ of substrate converted to product $\min ^{-1} \mathrm{~g}^{-1}$ crab tissue wet wt. LDH activities were measured in a medium of $80 \mathrm{mM}$ imidazole buffer, $1.0 \mathrm{M} \mathrm{KCl}, 3.25 \mathrm{mM} \mathrm{NADH}$, and $100 \mathrm{mM}$ Na Pyruvate. The reaction due to the oxidation of $\mathrm{NADH}$ was measured through the decrease in absorbance at $340 \mathrm{~nm}$. Activity measurements of CS were performed in a solution of $50 \mathrm{mM}$ imidazole buffer, $15 \mathrm{mM} \mathrm{MgCl}_{2}$, and $4 \mathrm{mM}$ DTNB (5,5-dithio-bis-2nitrobenzoic acid). The increase in absorbance at $412 \mathrm{~nm}$ due to the enzymatic reaction of the reduced coenzyme-A with DTNB was recorded after $40 \mathrm{mM}$ oxaloacetate had been added to the supernatant and cocktail solution. The background activity was noted before the addition of oxaloacetate and subtracted from the overall rate to derive the CS activity. ANOVA analyses were performed with StatView (v4.5, Abacus Concepts). Descriptive statistics were generated with KaleidaGraph (v3.6, Synergy Software).

\section{RESULTS}

\section{Field observations}

Over the course of this study, 97 specimens of Phacellophora camtschatica were analyzed for ectosymbionts. Megalopae and juveniles of Cancer gracilis were found congregating on the bell and oral arms of $P$. camtschatica, or hiding on the subumbrellar surface and oral arms when mildly disturbed. Male, female and juvenile Hyperia medusarum were concentrated on the oral arms of the medusae, and neither amphipods nor crabs were seen burrowing into the bell or gonads. Planktonic C. gracilis megalopae were absent from all zooplankton tows from the first week of June until mid-September. Ephyrae and small medusae $(<6 \mathrm{~cm})$ of $P$. camtschatica began to appear in early May. The medusae gradually increased in size over the summer months, and a second cohort appeared in early fall, as illustrated by the drop in minimum bell diameter in October (Fig. 2). No P. camtschatica were seen from November until May during this study.

Cancer gracilis megalopae were first seen riding medusae in early May, simultaneous with the first sightings of Phacellophora camtschatica at bell widths $\geq 3 \mathrm{~cm}$ (Fig. 3A). Sightings of the first instars on medusae soon followed in mid-May and increased into July (Fig. 3B). Because the abundance data are not displayed weekly, this rapid succession is not apparent in 


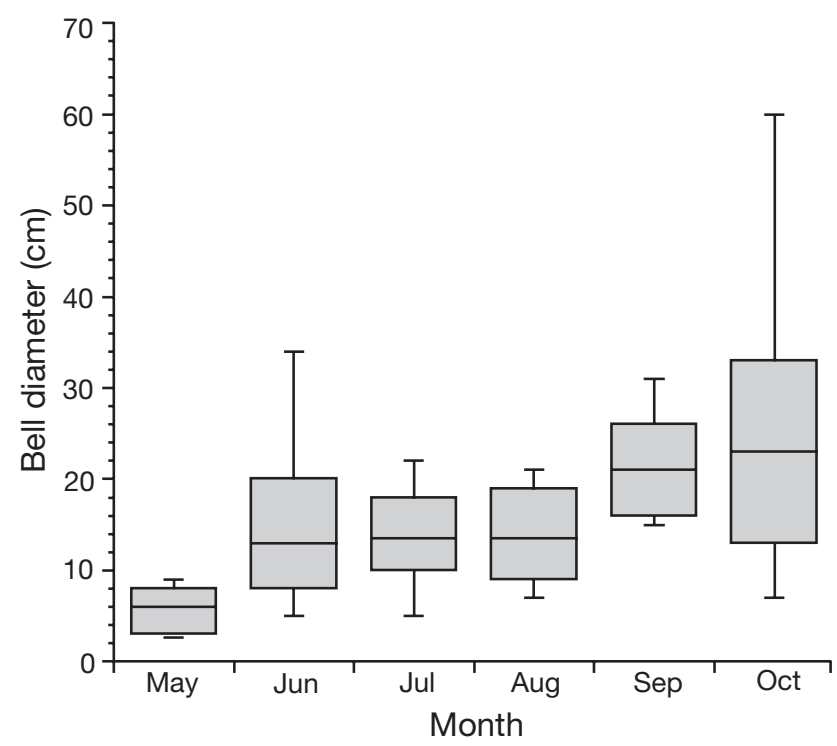

Fig. 2. Phacellophora camtschatica. Box and whiskers plot of bell diameter $(\mathrm{cm})$ medusae by month. Box represents central $50 \%$ of data, horizontal line the median, and limits of vertical line maximum and minimum measurements within each month. Minimum bell diameter increases until October, when a second cohort appears. For months May to October, $\mathrm{n}=14$, $21,20,12,14$ and 16 , respectively

Fig. 3. Instar stage ranged from $1^{\prime}$ to $5^{\prime}$. The frequency and number of riders rapidly increased into the months of June and July, with some medusae hosting more than 300 megalopae (maximum $=326$ ). The number of C. gracilis riders tapered off in August, re-surged in September, and dwindled in October (Fig. 3A,B). The percentage of $P$. camtschatica with megalopae peaked in spring and declined through the rest of the season (Fig. 4A); the prevalence of instars peaked in July (Fig. 4B).

Hyperia medusarum were also found riding Phacellophora camtschatica simultaneous with the first appearance of medusae in early May. Amphipods were abundant on medusae throughout the summer and into October, often numbering hundreds (maximum $=446$ ) on a single medusa (Fig. $3 \mathrm{C}$ ). Amphipods were found on the aboral surfaces and on the oral arms of the medusae. The prevalence of $H$. medusarum in the $P$. camtschatica population began with low infestation in the spring and then increased through early summer until leveling off at $100 \%$ in July (Fig. 4C). Every $P$. camtschatica inspected from mid-July through October was infested with scores or hundreds of $H$. medusarum adults and juveniles. The ratio of male (M) to female (F) H. medusarum on medusae was 1:1.4 M:F. The number of C. gracilis megalopae and $H$. medusarum per medusa did not correspond with the bell width of the host (Fig. 5A,B). The number of instars remained constant relative to bell width until Septem-
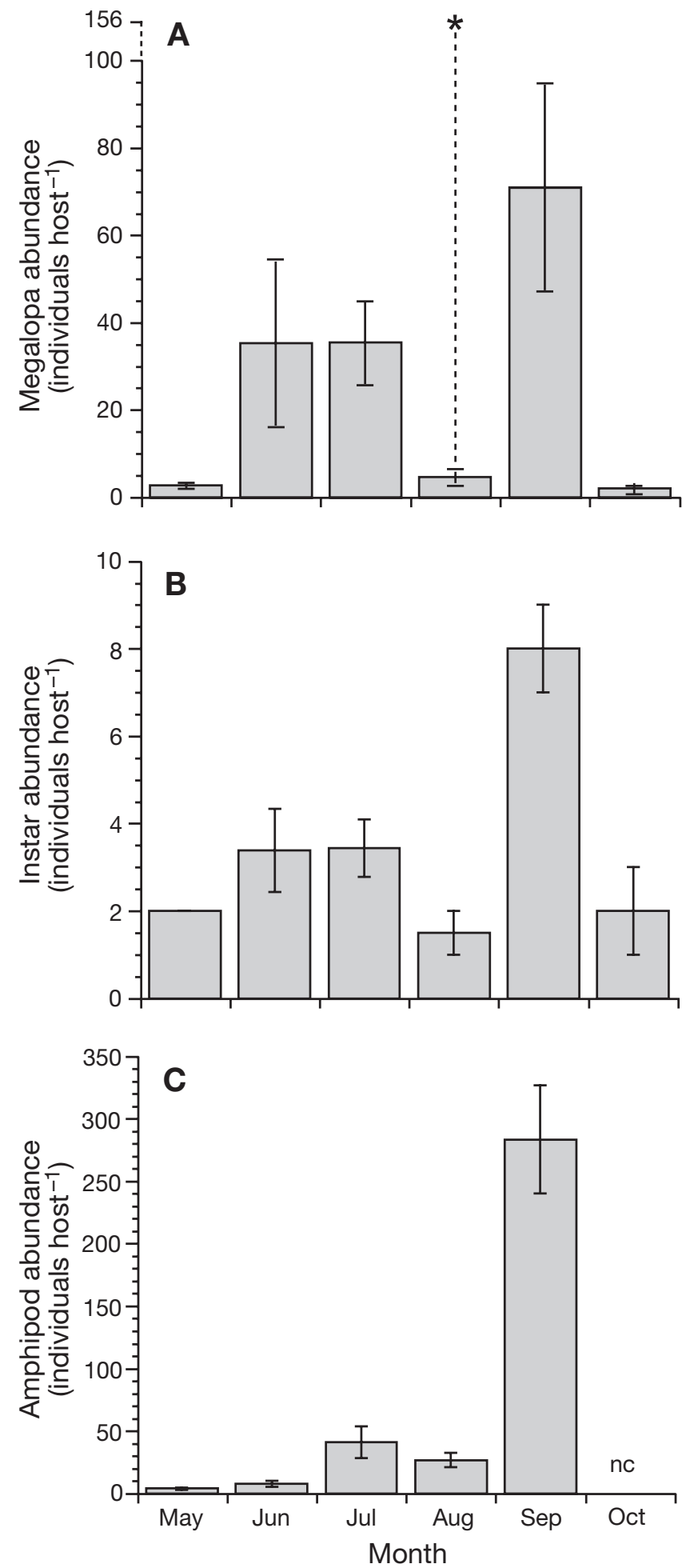

Fig. 3. (A) Cancer gracilis megalopae; (B) C. gracilis instars; (C) Hyperia medusarum juveniles and adults combined. Abundance (mean $\pm \mathrm{SE}$ ) of ectosymbionts on Phacellophora camtschatica in southern Puget Sound. In (A), single medusa with abundant megalopae is shown in August (*) but not included in data for bar chart. nc $=$ not counted. For months May to October, number of medusae analyzed $=14,21,20$, 12,14 and 16 , respectively 
ber (Fig. 5C), when there was a large increase in instar number relative to host width.

Phacellophora camtschatica was frequently found drifting near the periphery of large smacks of Aurelia labiata, typically with 1 to 3 A. labiata entrapped in the
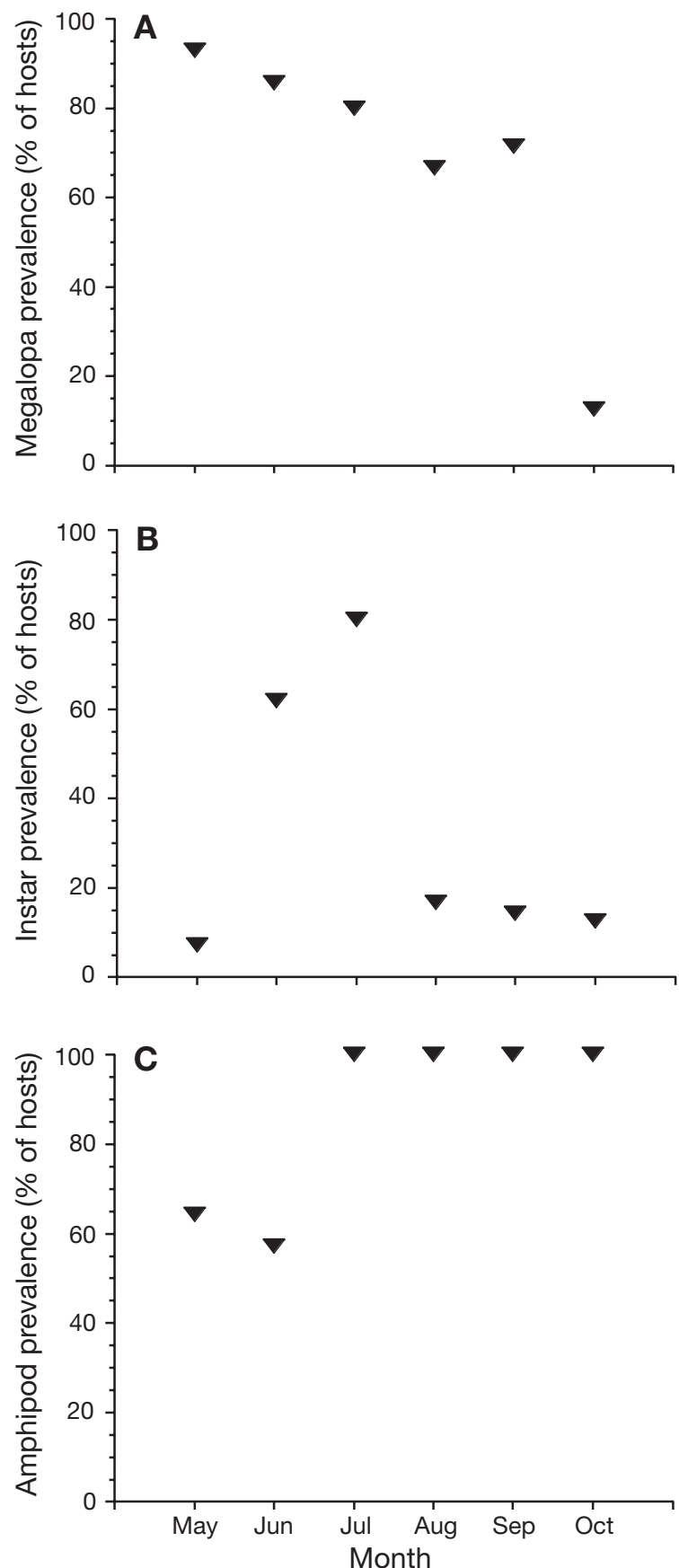

Fig. 4. (A) Cancer gracilis megalopae; (B) Cancer gracilis instars; (C) Hyperia medusarum. Prevalence of ectosymbionts of Phacellophora camtschatica in southern Puget Sound. Prevalence $=$ percentage of medusae in population sample that contain ectosymbionts. For months May to October, number of medusae analyzed $=14,21,20,12,14$, and 16 for each month, respectively oral arms along with various other gelatinous zooplankters including Pleurobrachia bachei and Aequorea victoria. During low tide, $P$. camtschatica was observed trailing tentacles along the bottom or aboral-side down at shallow depths. Commonly, individuals that were
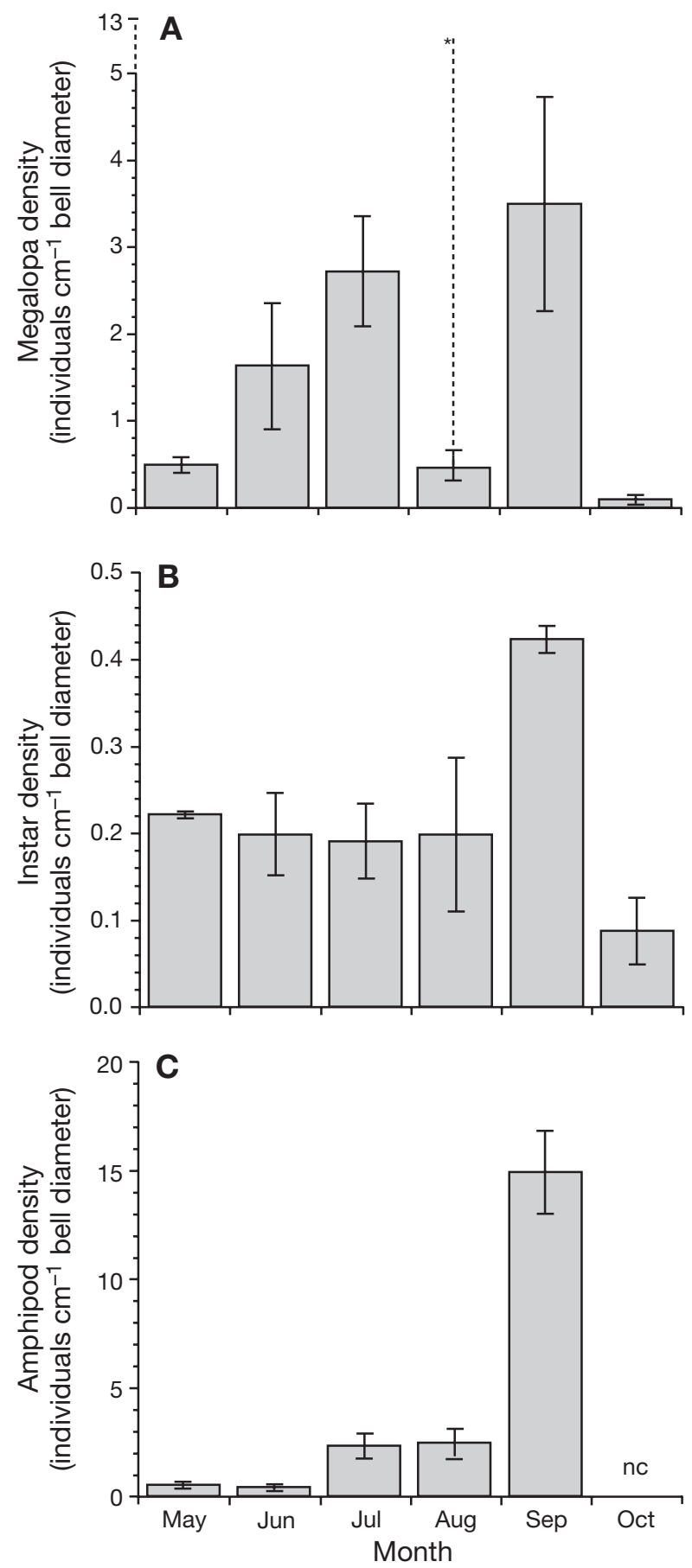

Fig. 5. (A) Cancer gracilis megalopae; (B) Cancer gracilis instars; (C) Hyperia medusarum juveniles and adults combined. Number (mean $\pm \mathrm{SE}$ ) of ectosymbionts relative to bell diameter of Phacellophora camtschatica by month. Further details as in Fig. 3 
aboral-side down were caught and preyed upon by adult Cancer productus and C. gracilis. Individuals caught on pilings and under floating docks were consumed by Pugettia producta and C. productus. Pile perch Rhacochilus vacca were observed plucking Hyperia medusarum from the medusae when these were ensnared on dock structures. Chum salmon Oncorhynchus keta were seen snatching pieces of the oral arms of $P$. camtschatica; however, it was unclear if the target was the medusa or its ectosymbionts.

Throughout the last decade, thousands of specimens of Aurelia labiata, Cyanea capillata and hydromedusae have been inspected visually for the presence of Cancer gracilis in southern Puget Sound, and no crabs have been observed. Observations of anthropogenically-derived and naturally occurring flotsam also failed to reveal the presence of C. gracilis. During the study period, pandalid shrimps were observed riding hydromedusae, but shrimp were never seen on A. labiata, C. capillata or Phacellophora camtschatica. With the exceptions of Muggiaea atlantica and Sarsia sp., Hyperia medusarum has been observed on all the species of southern Puget Sound hydromedusae listed in Rutherford \& Thuesen (2005), as well as on the 2 most common ctenophores, Pleurobrachia bachei and Bolinopsis infundibulum. Larval and juvenile $H$. medusarum have been observed throughout the winter in local populations of A. labiata, Polyorchis penicillatus, Aequorea victoria and Pleurobrachia bachei.

\section{Laboratory observations}

Cancer gracilis megalopae and instars displayed an ontogenetic shift in their prey items in the laboratory. Megalopae were observed ingesting Artemia franciscana nauplii and Phacellophora camtschatica tentacles in both the planktonkreisel and under the dissection microscope. Instars were observed to consume all developmental stages of $A$. franciscana and Hyperia medusarum, Aurelia labiata, and tentacles of $P$. camtschatica (Fig. 6A). Instars were observed cannibalizing megalopae, smaller instars and post-ecdysic instars of similar size. Instars through Stage $3(n=6)$ discarded adult Artemia franciscana in favor of nauplii when offered an assortment of stages. Instars ingesting amphipods pried open the carapace and extracted the internal mass, discarding the chitinous exoskeleton and appendages. This feeding behavior was observed both in the planktonkreisel and under the dissection microscope. Instars scrambled from their positions on the bell of their host to feed on Aurelia labiata captured by $P$. camtschatica, stripping off and eating sections of the exumbrella (Fig. 6B). Instars also plucked and ate bits of the oral arms from the host that were in contact with the en-
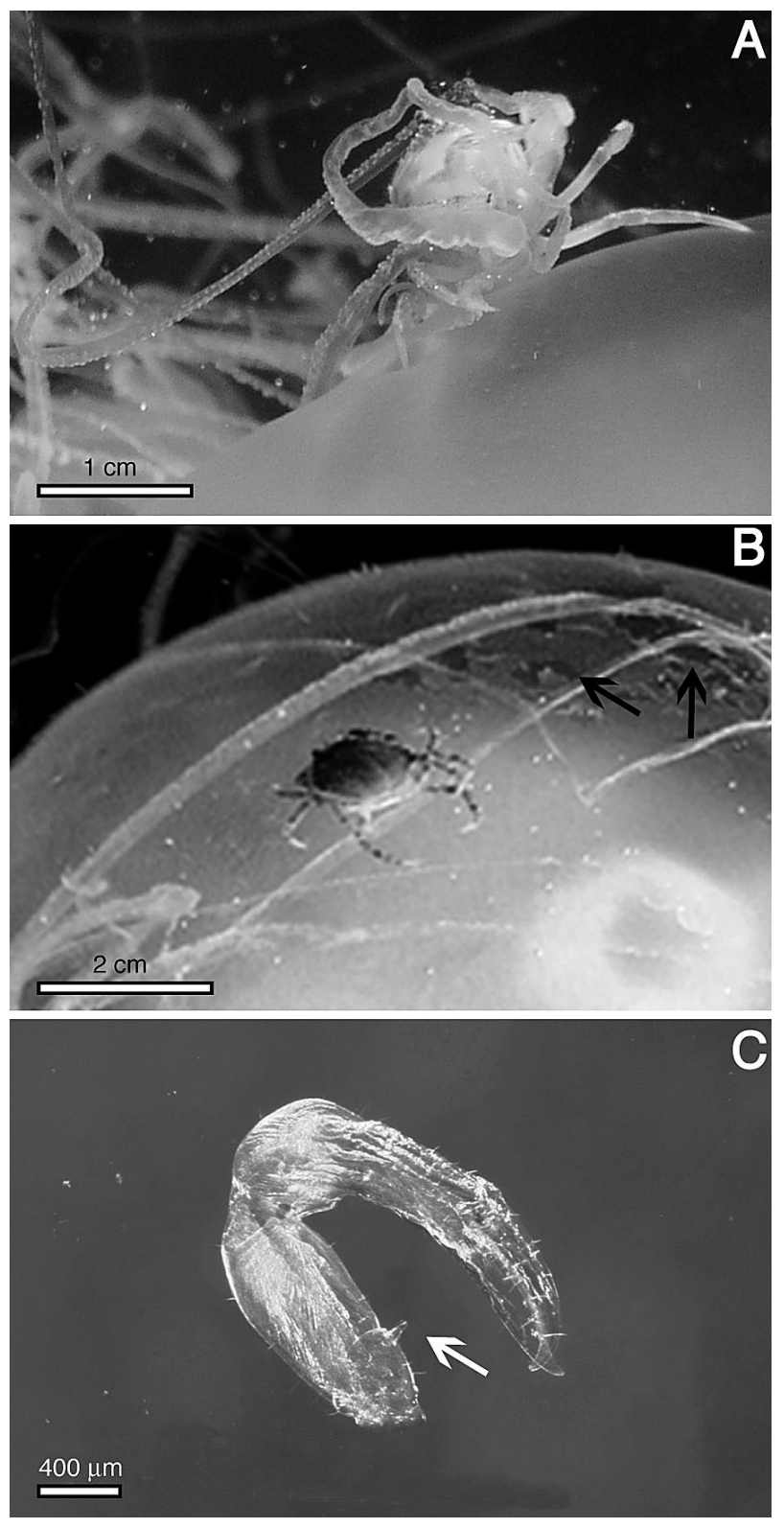

Fig. 6. (A) Cancer gracilis 3' instar eating tentacle of Phacellophora camtschatica while riding its bell. (B) C. gracilis instar eating epidermis of Aurelia labiata medusa captured by the host, P. camtschatica; arrows indicate areas of epidermis eaten by the crab. (C) Cheliped from C. gracilis megalopa; arrow indicates spine on ischium of the cheliped used to stabilize crab on the medusa

gulfed prey. Some surfaces of the planktonkreisel became fouled by scyphistomae of either A. labiata or $P$. camtschatica during the study. $H$. medusarum that attempted to rest and/or prey on scyphistomae were instead captured by the scyphistomae despite their struggles to escape. A specimen of $P$. camtschatica bearing $>22$ adult $H$. medusarum was introduced into a planktonkreisel containing 4 C. gracilis instars (3' to 5'). 
After 14 h, 1 Instar 4' and 2 Instar 3' were riding the medusa and only 3 amphipods remained on the medusa or in the planktonkreisel. Isolating 9 amphipods with 6 instars in a $100 \mathrm{ml}$ container resulted in the consumption of every amphipod within $7 \mathrm{~h}$.

Instars attempting to board a host assumed a posture different from that used to capture food. To grasp prey items, instars perched themselves on the 4th and 5th pereopods with their chelipeds raised. Instars preparing to mount their hosts braced themselves on their chelipeds and 2nd Pereopods while waving Pereopods 4 and 5 to clasp onto the portion of the medusa that drifted within reach. Instars displayed territorial behaviors, occupying distal positions on the bell when more than one crab was hosted at a time and wrangling when in proximity of each other. Of 4 benthic instars collected from subtidal habitats, 3 were riding within $16 \mathrm{~h}$ of introduction to a planktonkreisel with Phacellophora camtschatica. Although Instars 5' would ride continuously for more than $10 \mathrm{~d}$ in the planktonkreisel, no instars beyond this stage could be induced to ride. Microscopical examination of Cancer gracilis megalopae revealed the pronounced spine on the ventrodistal margin of the ischium of the cheliped (Fig. 6C) (Ally 1975, DeBrosse et al. 1990). This spine was observed to help stabilize megalopae as they rode medusae.

\section{Behavioral experiments}

Experiments conducted in the planktonkreisel with Cancer gracilis demonstrated that both megalopae and instars would attempt to ride objects other than Phacellophora camtschatica.

Cancer gracilis and Aurelia labiata. Cancer gracilis instars ( $\mathrm{n}=4$ ) were introduced into a planktonkreisel containing Aurelia labiata. Within 20 min, an Instar 4' was observed riding 1 of the A. labiata and eating its epidermal tissue. An Instar 5' readily rode another $A$. labiata when placed on the surface of its bell, also ingesting sections of epidermis from the exumbrella. It was observed that the weight of a single crab on the aboral surface of $A$. labiata was sufficient to pull the medusa aboral side down. Since $A$. labiata is a much more vigorous swimmer than Phacellophora camtschatica, instars were forced to grip very firmly to maintain their positions. The entire lengths of the dactylopodites of the gripping legs penetrated the epidermis and mesoglea of the A. labiata, whereas the exumbrella of $P$. camtschatica was never damaged by the pereopods of the crabs. Instars clung to deteriorating specimens of $A$. labiata for $3 \mathrm{~d}$ in the planktonkreisel before the medusae were removed. Megalopae ( $\mathrm{n}=10$ ) were unable to secure themselves to $A$. labiata, which generates currents too turbulent to allow megalopae to gain purchase. Furthermore, megalopae $(\mathrm{n}=10)$ that came into contact with mucus produced by $A$. labiata were entrapped and died within 20 min. Instars $(n=5)$ riding $A$. labiata immediately moved onto the surface of their usual hosts when A. labiata were captured by P. camtschatica. Because all A. labiata were captured quickly by P. camtschatica, no instars were observed to switch hosts independently, and host preference could not be demonstrated.

Cancer gracilis and the pseudomedusa. An instar placed onto the surface of a pseudomedusa was voluntarily joined by the 2 other instars (Fig. 1) present in the planktonkreisel. More than 26 of 40 megalopae in the planktonkreisel attached to the pseudomedusa in $<1.5 \mathrm{~h}$. Instars collected Artemia franciscana nauplii that settled onto the surface of the pseudomedusa. Hyperia medusarum released into the planktonkreisel promptly attached to the pseudomedusa, but were preyed on by Cancer gracilis instars and abandoned the pseudomedusa after approximately $0.5 \mathrm{~h}$. Megalopae and instars continued to cling to the pseudomedusa for more than $24 \mathrm{~h}$, until it was removed from the planktonkreisel. In a separate experiment, all instars ( $\mathrm{n}=3)$, but only 1 megalopa $(\mathrm{n}=40)$, switched 'host' after the introduction of a specimen of Phacellophora camtschatica into the planktonkreisel with the pseudomedusa.

\section{Fecal pellet analyses}

Microscopical examination of the fecal pellets from field-caught Cancer gracilis (instars, $\mathrm{n}=8$ ) revealed a diverse mixture of prey remains (Fig. 7A). Fecal pellets contained unspecified crustacean exoskeletons $(72 \%)$, nematocysts $(20 \%)$ in both undischarged and discharged states, and diatom frustules (8\%) within a matrix of finely digested material. Pellets from instars $(n=5)$ fed only amphipods for $3 \mathrm{~d}$ contained very few exoskeleton components. Fecal pellets $(\mathrm{n}=12)$ of juvenile, female and male Hyperia medusarum were full of nematocysts (Fig. 7B), and only 2 non-nematocyst identifiable particles (1 diatom part and 1 crustacean exoskeleton fragment) were observed.

\section{Stable isotope analyses}

The natural abundance ratios of ${ }^{13} \mathrm{C}$ and ${ }^{15} \mathrm{~N}$ in Cancer gracilis, Phacellophora camtschatica, Hyperia medusarum and some other zooplankters from southern Puget Sound are shown in Table 1. Both stable 

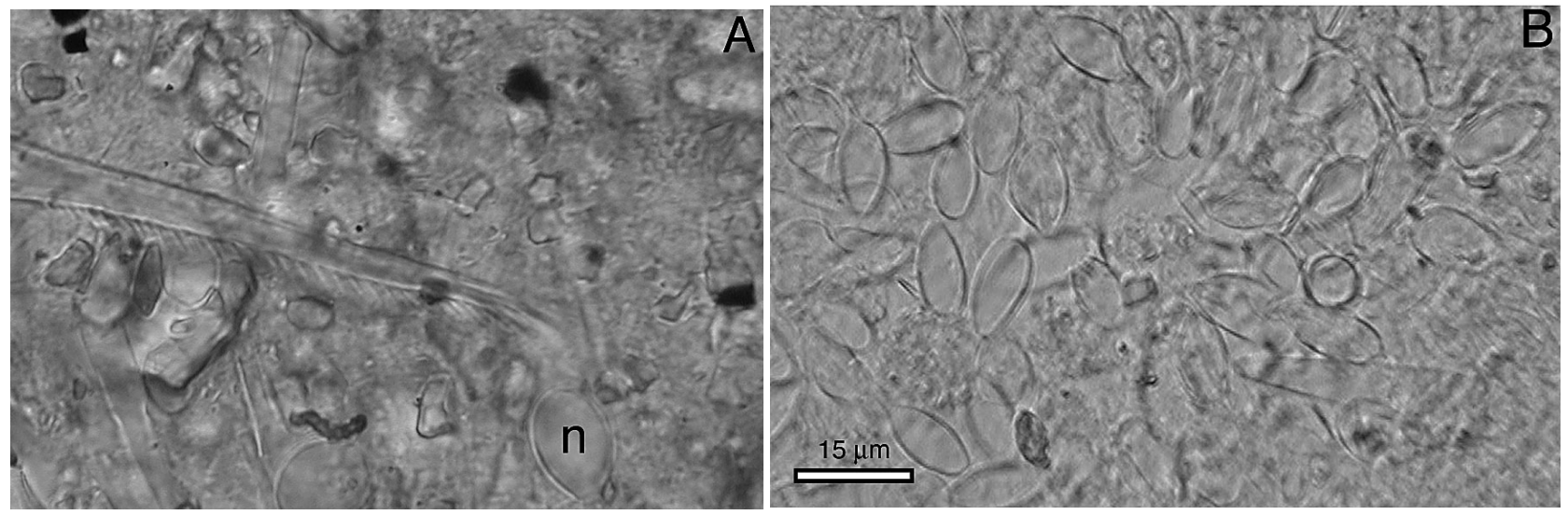

Fig. 7. Typical fecal pellet contents of crustacean ectosymbionts of Phacellophora camtschatica in southern Puget Sound. (A) Fecal pellet contents of instar of Cancer gracilis; various crustacean parts are visible; $\mathrm{n}=$ nematocyst. (B) Nematocysts in fecal pellet contents of adult male Hyperia medusarum

isotopes were greatly enriched in mesoglea of $P$. camtschatica compared with gonad and oral arm tissue (Fig. 8). $\delta^{13} \mathrm{C}$ and $\delta^{15} \mathrm{~N}$ values varied between the organisms (Fig. 9). The greatest variation in both $\delta^{13} \mathrm{C}$ and $\delta^{15} \mathrm{~N}$ was in juvenile crabs (Fig. 9), indicating a broad diet. Both $\delta^{13} \mathrm{C}$ and $\delta^{15} \mathrm{~N}$ were similar among juvenile, male and female amphipods, suggesting that these all occupied the same trophic level. The lowest values of $\delta^{13} \mathrm{C}$ were found in gelatinous zooplankton,

Table 1. $\delta^{13} \mathrm{C}(\%)$ and $\delta^{15} \mathrm{~N}(\%)$ (means $\pm 1 \mathrm{SD}$ ) content of member of 3-way symbiosis between Cancer gracilis, Phacellophora camtschatica and Hyperia medusarum and content of other zooplankton specimens from Budd Inlet, southern Puget Sound. $n_{i} n^{*}$ : no. of samples; no. of specimens pooled in each sample (nc: not counted)

\begin{tabular}{|llll|}
\hline Specimen & $\delta^{13} \mathrm{C}(\%)$ & $\delta^{15} \mathrm{~N}(\%)$ & \multicolumn{1}{c|}{$\mathrm{n}_{;} \mathrm{n}^{*}$} \\
\hline Cancer gracilis & & & \\
Megalopae & $-19.9 \pm 0.5$ & $11.4 \pm 1.7$ & $3 ; 15^{*}, 17^{*}, 113^{*}$ \\
Juvenile & $-22.4 \pm 2.8$ & $14.2 \pm 3.3$ & $3 ; 6^{*}, 3^{*}, 3^{*}$ \\
Adult & -16.3 & 12.8 & 1 \\
Phacellophora camtschatica & & \\
Whole body & $-25.7 \pm 1.2$ & $15.0 \pm 0.2$ & 4 \\
Gonad & $-27.6 \pm 0.7$ & $14.9 \pm 0.2$ & 2 \\
Oral arm tissue & $-24.4 \pm 1.1$ & $13.6 \pm 0.9$ & 2 \\
Mesoglea & $-10.1 \pm 0.9$ & $16.5 \pm 0.1$ & 2 \\
Hyperia medusarum & & & \\
Males & $-19.6 \pm 0.3$ & $12.5 \pm 0.1$ & $2 ; 29^{*}, 26^{*}$ \\
Females & $-18.9 \pm 0.9$ & $12.0 \pm 0.3$ & $3 ; 72^{*}, 31^{*}, \mathrm{nc}^{*}$ \\
Juveniles & -20.5 & 12.3 & $1 ; 26^{*}$ \\
Hydromedusae & & & \\
Polyorchis penicillatus & -26.4 & 15.8 & $1 ; 2^{*}$ \\
$\begin{array}{l}\text { Muggiaea atlantica } \\
\text { Phialidium lomae }\end{array}$ & -30.0 & 15.2 & $1 ; 200^{*}$ \\
Other planktonic crab larvae & -29.2 & 15.8 & $1 ; 75^{*}$ \\
Cancer spp. zoeae & -25.8 & 13.6 & $1 ; 20^{*}$ \\
Cancer spp. megalopae & -21.8 & 11.9 & $1 ; 12^{*}$ \\
Porcelain crab zoeae & -20.3 & 10.4 & $1 ; 56^{*}$ \\
\hline
\end{tabular}

and ${ }^{13} \mathrm{C}$ enrichment was distinctly highest in the benthic specimen of C. gracilis (Fig. 9).

\section{Oxygen consumption rates}

Rates of oxygen consumption were measured for Cancer gracilis megalopae and instars (Table 2). The background rate of bacterial oxygen consumption was less than $0.5 \%$ in all controls. No significant differences were found between the massspecific oxygen consumption rates of megalopae that were riding $(n=7)$ compared to those that were free-living $(\mathrm{n}=10)$ (Table 2). Instars $(n=13)$ demonstrated a significantly lower rate than either megalopal group (ANOVA, $\mathrm{p}=0.036$ ). Based on a mean combined consumption rate of $7.88 \mu \mathrm{mol} \mathrm{O}_{2} \mathrm{~g}^{-1}$ $\mathrm{h}^{-1}$, the daily energetic ration for megalopae was calculated at $0.021 \mathrm{~J}_{\text {individual }}{ }^{-1} \mathrm{~d}^{-1}$.

\section{Enzymatic activity}

LDH and CS activities were measured for instars $(\mathrm{n}=7)$ and for riding $(\mathrm{n}=8)$ and freeliving $(n=7)$ megalopae (Table 2). The LDH activities of instars were significantly different from those of both groups of megalopae (ANOVA, $\mathrm{p}<0.01$ ). There were no significant differences in LDH activities between the 2 groups of megalopae, indicating that there are no differences in the glycolytic potentials between riding and swimming megalopae. There were no significant differences in CS activities between the 3 groups of crabs, indicating similar aerobic metabolic potential. 


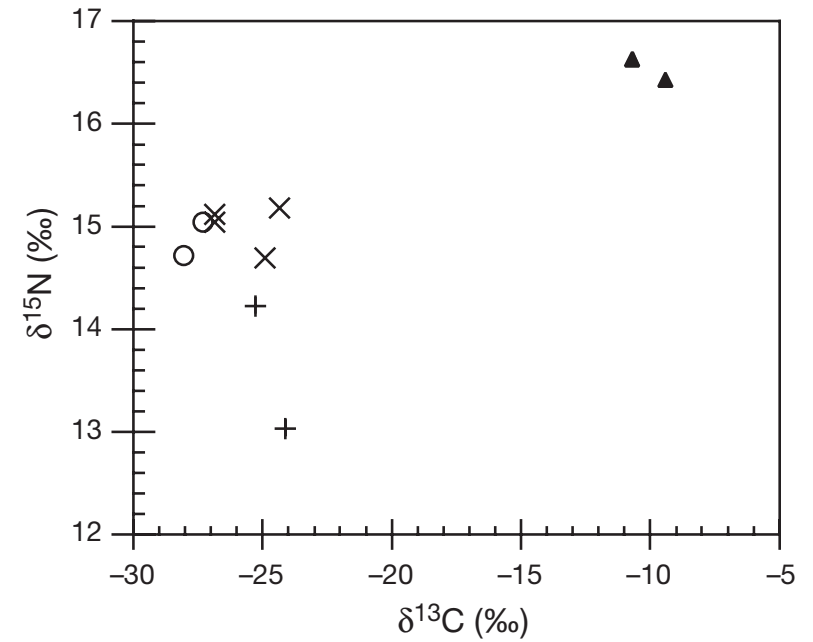

Fig. 8. Phacellophora camtschatica. Dual isotope plot for whole organism homogenates $(\mathrm{x})$, oral arms $(+)$, gonads $(0)$, and mesoglea $(\mathbf{\Lambda})$ of scyphomedusa in southern Puget Sound

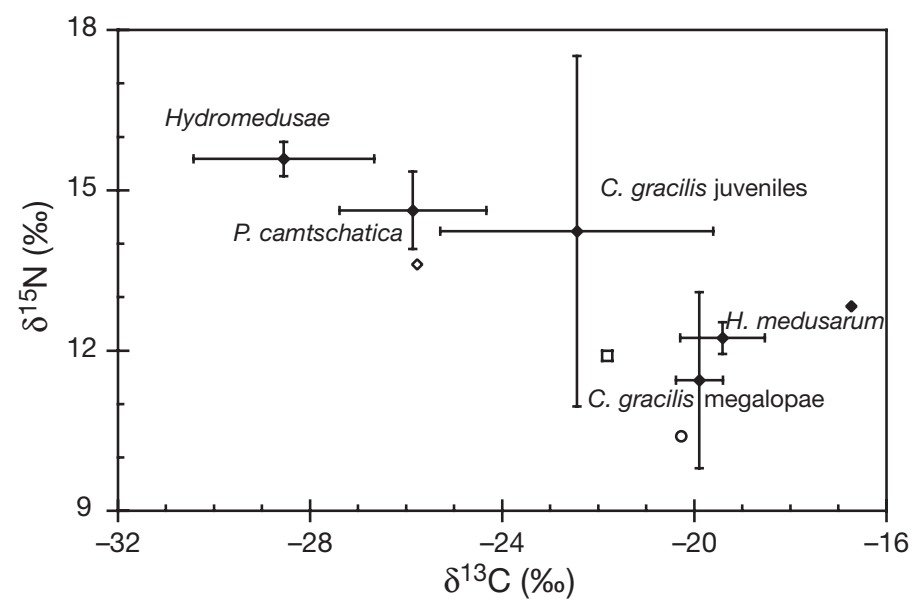

Fig. 9. Cancer gracilis, Phacellophora camtschatica, Hyperia medusarum and other planktonic organisms in southern Puget Sound. Dual isotope plot of $\delta^{13} \mathrm{C}$ and $\delta^{15} \mathrm{~N}$ (means $\pm 1 \mathrm{SD}$ ). Values for $P$. camtschatica include measurements from whole organism homogenates, gonads and oral arms, but not mesoglea. Juvenile, female and male specimens are included in values for $H$. medusarum. Measurements on (O) planktonic porcelain crab zoeae, $(\diamond)$ planktonic Cancer spp. zoeae, and ( $\square$ ) planktonic Cancer spp. megalopae were measured on pooled individuals; data for 1 adult C. gracilis ( ) caught in a benthic trap are also shown (see Table 1 for pooling details)

Table 2. Cancer gracilis. Oxygen consumption and enzymatic activities of megalopae and instars. Values are mean \pm SE (n). LDH: lactate dehydrogenase, CS: citrate synthase

\begin{tabular}{|lllcc|}
\hline Stage & $\begin{array}{c}\text { Wet weight } \\
(\mathrm{mg})\end{array}$ & $\begin{array}{c}\mathrm{O}_{2} \text { consumption } \\
\left(\mu \mathrm{mol} \mathrm{O} \mathrm{g}^{-1} \mathrm{~h}^{-1}\right)\end{array}$ & $\begin{array}{c}\text { LDH activity } \\
\left(\mathrm{U} \mathrm{g} \mathrm{g}^{-1}\right)\end{array}$ & $\begin{array}{c}\text { CS activity } \\
\left(\mathrm{U} \mathrm{g} \mathrm{g}^{-1}\right)\end{array}$ \\
\hline Megalopae & & & & \\
Epibiotic & $2.56 \pm 0.12(7)$ & $8.83 \pm 0.79(7)$ & $8.88 \pm 0.98(8)$ & $2.80 \pm 0.17(8)$ \\
Planktonic & $2.48 \pm 0.01(10)$ & $7.54 \pm 0.49(10)$ & $6.18 \pm 0.92(7)$ & $2.21 \pm 0.28(7)$ \\
Instars & $6.07 \pm 0.28(13)$ & $6.43 \pm 0.34(13)$ & $4.27 \pm 0.44(7)$ & $2.08 \pm 0.17(7)$ \\
\hline
\end{tabular}

\section{DISCUSSION}

Symbioses between brachyuran crabs and pelagic cnidarians have been documented worldwide (Table 3); 4 families (Cancridae, Dorippidae, Majidae and Portunidae) and at least 5 genera are represented by these observations. About one-third of the associations reported are of swimming crabs, one-third the spider crab Libinia dubia, and the remaining third Cancer spp. Most of these associations are thought to be facultative and commensal (e.g. Phillips et al. 1969, Morton 1989), although 3 crabs were reported feeding on their host (Jachowski 1963, Phillips et al. 1969, Wickham 1979). Many crab-jellyfish associations involve crabs only in juvenile stages of development, and all the reported associations involving $C$. gracilis document crabs during the megalopal or juvenile stages. Nearly all were reported as epibionts clinging to the bell or oral arms of their host medusa. Although these associations are widely recognized, the defining characteristics of the symbioses between crabs and planktonic cnidarians have remained largely unknown until now. The present investigation is particularly interesting, because it relates the interactions between 2 different symbionts, C. gracilis and Hyperia medusarum, with one host, Phacellophora camtschatica.

\section{Seasonal population changes}

The abundance of Cancer gracilis megalopae (frequently numbering hundreds) on Phacellophora camtschatica in conjunction with their absence from zooplankton tows and flotsam from June until September of 2003 suggests that the majority of C. gracilis megalopae in the region were riding the medusae during this period. Browne \& Kingsford (2005) found the commensal copepod Paramacrochiron maximum to be extremely abundant on the scyphozoan Catostylus mosaicus while scarce in the water column and concluded that the copepod was a commensal symbiont. A similar phenomenon was reported from an abundance assessment of Cancer magister conducted offshore from California. C. magister megalopae were found riding Velella velella in large numbers; however, the megalopae were sparse or absent in plankton sampling tows while $V$. velella was present (Wickham 1979). In southern Puget Sound, P. camtschatica medusae were first found in April and persisted through October. The 7 mo hatching season of C. gracilis, beginning in March and continuing through the summer into August 


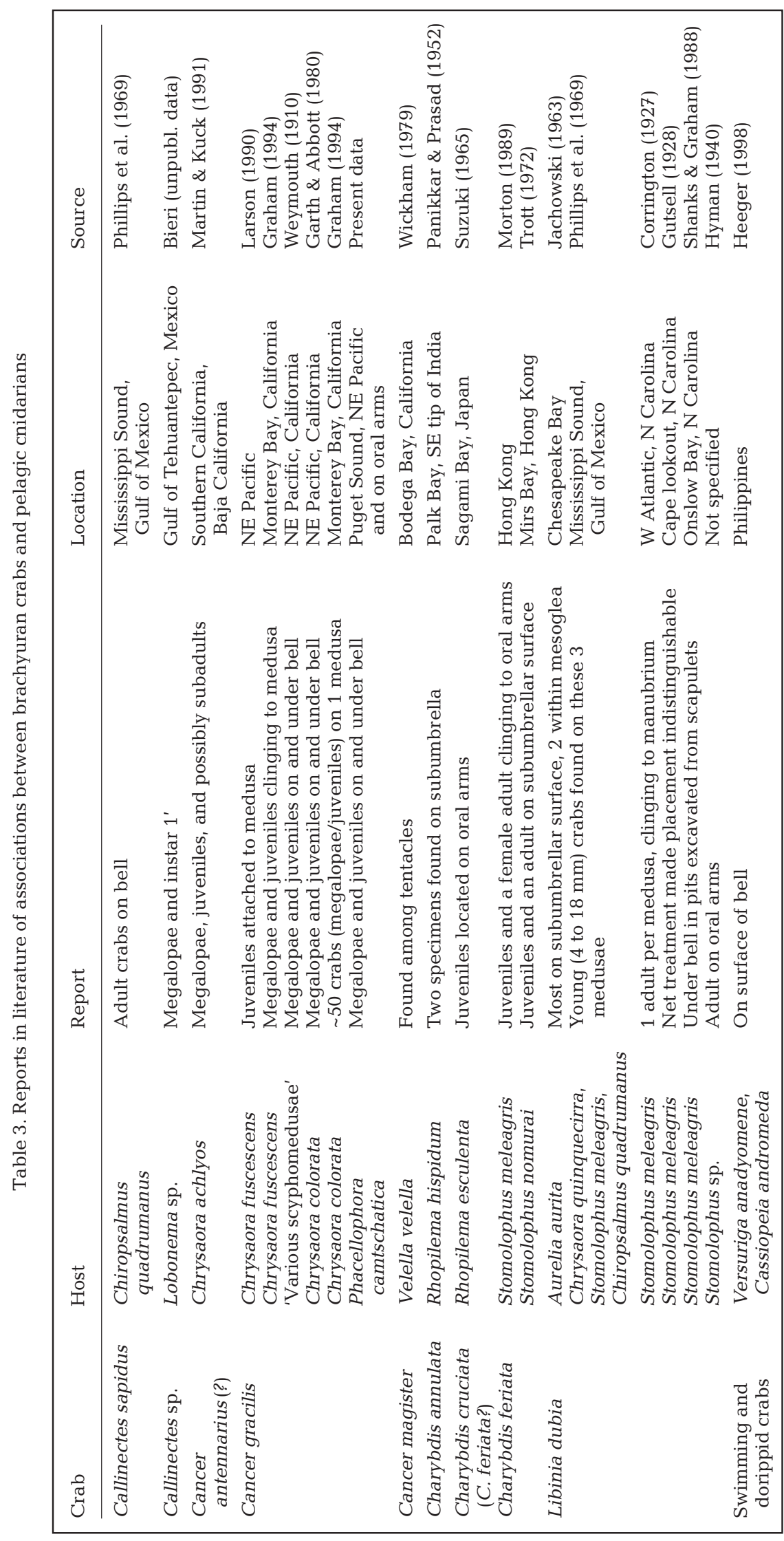

(Orensanz et al. 1995 ), precedes the seasonal periodicity of $P$. camtschatica. Megalopae follow approximately 6 wk later, from the end of April into October (Sulkin \& McKeen 1994, Orensanz et al. 1995). In the present study, megalopae appeared as riders nearly concurrently with the first sightings of the medusae in the spring, and they were carried by hosts that had just exited the ephyra stage $(3 \mathrm{~cm}$ diameter). Instars appeared on medusae within 2 wk of the appearance of megalopae. Decreases in megalopa abundance in August and October in combination with the continual increase in bell diameter indicated that the number of megalopal riders was independent of host size. During this study, C. gracilis megalopae were absent from zooplankton tows from the time they appeared on their hosts until mid-September, when the second large cohort of crab larvae appeared both in tows and on the medusae.

The number of instars per host was dramatically fewer than the number of megalopae. Cannibalism of smaller and post-ecdysic individuals may have been partially responsible for the decrease in the number of megalopae and instars as they matured. The decrease could also have resulted from territorial disputes between instars. While Phacellophora camtschatica may provide protection from predation for the young crabs, this defense is not complete. Birds and fishes are known to consume medusae and their symbionts (Harrison 1984, Arai 1988, Ates 1991). The presence of amphipods and crabs may also increase predation on the jellyfish, as has been found in other epibiotic associations (Wahl \& Olaf 1999), since the predators incidentally consume the host as they attempt to pluck the crustaceans from the bell and oral arms. Monopolization of the host is common in other symbiotic relation- 
ships involving crustaceans, especially when the size of the symbiont is relatively large in relation to that of the host (Thiel \& Baeza 2001).

Field studies, fecal pellet analyses, and isotopic data indicate that juvenile, female and male Hyperia medusarum were subsisting directly on Phacellophora camtschatica. By the end of the summer, scores (frequently hundreds) of $H$. medusarum occupied every $P$. camtschatica in this study. Adult males were found clinging to the medusae throughout the season. The 1:1.4 ratio of M:F $H$. medusarum observed in this study is close to the 1:1.3 M:F ratio found by Dittrich (1988) among $H$. galba associated with scyphomedusae in the North Sea. Dittrich (1988) attributed the fall increase of the hyperiid amphipod H. galba in scyphozoans to an increase in water temperature, as warmer water allowed higher growth rates in juveniles that hatched in mid-summer. The summer cohort was presumed to reach sexual maturity in the fall and produce benthic offspring that hibernated over winter, possibly on scyphistomae of Aurelia aurita. If $H$. medusarum is as susceptible to the stinging cells and apparently superior digestive action of scyphistomae in the field as it was in the planktonkreisel, it is unlikely that the amphipods survive by inhabiting and preying on scyphistomae. Our observations in this study have shown that juvenile $H$. medusarum in southern Puget Sound are overwintering in gelatinous zooplankton.

\section{Host choice}

The megalopae in this study swam directly toward a potential host that was within proximity, but the stimulus to ride may be triggered by direct contact with the host. Other Cancer spp. larvae require direct contact with prey species to initiate feeding (Hinz et al. 2001). The spine on the cheliped of C. gracilis megalopae (Ally 1975, DeBrosse et al. 1990) may enhance the ability of this crab to grip the tentacles of its gelatinous host, however C. productus also sports this spine and is not known to participate in any riding activities. $C$. gracilis instars may ride continuously from the megalopal stage or initiate the association when the medusae trail on the bottom. The instars in this study readily clambered onto their usual host, as well as onto Aurelia labiata and the pseudomedusa, when offered the opportunity in the planktonkreisel. Indiscriminate choice of host in the laboratory was also found in associations between Libinia dubia and various scyphomedusae found in the Mississippi Sound (Phillips et al. 1969). Differences in association rates with Chrysaora quinquecirrha at the bottom and the surface led to the suggestion that $L$. dubia forms temporary associations when the jellyfish are near the bottom. The display of behavior specific to grasping the host seen in this study suggests that $C$. gracilis instars may also be able to initiate the relationship from the bottom in addition to establishing ridership as megalopae.

Megalopae demonstrated a willingness to accept other hosts, successfully boarding the pseudomedusa and attempting to ride Aurelia labiata in the planktonkreisel. Megalopae, however, were unable to board A. labiata due to its strong swimming movements and sticky mucus. Instars cannot board A. labiata in the field because these medusae do not slowly drift along the bottom as Phacellophora camtschatica sometimes does. Thus, Cancer gracilis is proscribed from riding $A$. labiata in a natural setting.

Cancer gracilis larvae appear to be unaffected by the nematocysts of their host, as evidenced by their habits of hiding among the tentacles and eating nematocystcontaining tentacle tissue. Other symbiotic crabs also eat the tentacles of their hosts. Megalopae of C. magister are known to eat tentacles of Velella velella (Wickham 1979), and Libinia dubia can consume nematocysts of Stomolophus meleagris without any adverse effects (Shanks \& Graham 1988). In a previous study of $C$. productus and C. gracilis megalopae in relation to Chrysaora fuscescens, Graham (1994) concluded that $C$. productus was susceptible to the sting of the medusa, and in laboratory experiments, C. productus preferred to associate with cotton balls and algae over medusae. In his study, C. gracilis was unaffected by toxins and rode Chrysaora fuscescens for $>10 \mathrm{~d}$. The adult stages of C. gracilis, C. productus and Pugettia producta feed on Phacellophora camtschatica when it rests on the bottom, and they appear to be unaffected by the sting of its nematocysts. The higher potency of the nematocysts of Cyanea capillata may prevent $C$. gracilis from associating with this other common scyphomedusa in southern Puget Sound.

\section{Trophic relationships}

The fecal pellets from instars and megalopae collected in the field contained much higher proportions of crustacean remnants than nematocysts, supporting ingestion observations made in the laboratory. Although Cancer gracilis instars clearly harvested amphipods from their hosts, their fecal pellets failed to distinctly exhibit the exoskeletons of Hyperia medusarum. This is due to the manner in which amphipods were consumed, since the majority of chitinous structures were discarded as the crab extracted the soft inner mass of the amphipod. The presence of diatom frustules in crab fecal pellets may represent incidental consumption or a continuation of early larval feeding patterns (Sulkin \& McKeen 1999). 
Although Cancer gracilis sometimes feeds on its host, the majority of its diet comes from other prey. Megalopae and instars collect much of their food from the oral arms and the umbrellar surfaces of the jellyfish, either having settled there incidentally or having been caught as prey by the medusae. Instars readily harvest the hyperiid parasitoids from the oral arms of their host. The large population of Hyperia medusarum in September was sufficient to support the high instar density, since crabs disappeared before they consumed all the amphipods. Similarly, symbiotic crabs feed on epibionts (including amphipods, barnacle cyprids, and other crabs) of the green turtle Chelonia mydas and the loggerhead turtle Caretta caretta (Davenport 1994, Frick et al. 2002). These crabs were deemed 'beneficial symbionts' because of their reduction of debilitating effects and of drag on the host (Frick et al. 2000). Phacellophora camtschatica likewise may benefit from the presence of Cancer gracilis instars, which consume $H$. medusarum in a facultative cleaning association.

\section{Stable isotope analyses}

The $\delta^{13} \mathrm{C}$ values reflect expected trophic relationships between hydromedusae, Phacellophora camtschatica, Hyperia medusarum and Cancer gracilis. The $\delta^{13} \mathrm{C}$ signatures of the megalopae reflect a diet similar to that of $H$. medusarum, and imply that, for nourishment, megalopae have a heavier reliance on the medusa itself than do the instars. This agrees with behavioral observations. The large difference in $\delta^{13} \mathrm{C}$ representing 1 trophic step between $P$. camtschatica to $H$. medusarum may indicate that the amphipod is getting some of its carbon from mesoglea. The same may be true for the megalopae. The broad range of carbon and nitrogen stable isotope ratios of $C$. gracilis instars collected from $P$. camtschatica reflect the diversity of diet seen in behavioral observations and fecal pellet samples. The trophic position of $C$. gracilis as revealed by $\delta^{13} \mathrm{C}$ values is consistent with observations of instars consuming both the prey and the parasitoids of their host. Planktonic Cancer spp. zoeae had lower $\delta^{13} \mathrm{C}$ values than the other $C$. gracilis samples. The adult crab had the most enriched carbon isotope ratios, indicating a higher trophic position for benthic adults. Because isolated muscle tissue was used, there was no chitin in the adult specimen, and this may have influenced these ratios compared to those of juvenile specimens (Schimmelmann \& DeNiro 1986).

The $\delta^{15} \mathrm{~N}$ data are more difficult to interpret than the carbon data. Hydromedusae are a food source for Phacellophora camtschatica, but the $\delta^{15} \mathrm{~N}$ values indicate that some other source of nitrogen is also being uti- lized. Nitrogen of all the Cancer gracilis samples overlap, and it appears that crabs are getting nitrogen from a lower trophic source. The diatom frustules in the fecal pellets of juvenile crabs indicate that this is certainly true. The stable isotope ratios of Cancer spp. megalopae caught with the zooplankton net were intermediate between the ectosymbiont megalopae and juveniles, indicating that the diets of ectosymbiotic megalopae and free-living planktonic megalopae differ.

The natural abundance of stable isotopes in estuarine zooplankton is known to vary significantly with location and season (Simenstad \& Wissmar 1985, Montoya et al. 1990), and caution has to be taken when comparing stable isotope ratios in food-chain studies (Peterson \& Fry 1987). The $\delta^{15} \mathrm{~N}$ values of Phacellophora camtschatica in Puget Sound are similar to those of other scyphomedusae (Montoya et al. 1990, Brodeur et al. 2002), however its $\delta^{13} \mathrm{C}$ values are lower than those of other scyphomedusae (Malej et al. 1993, Brodeur et al. 2002). The stable isotope ratios of hydromedusae in this present report are slightly depleted in ${ }^{13} \mathrm{C}$ and enriched in ${ }^{15} \mathrm{~N}$ compared with those reported previously for hydromedusae from the Bering Sea (Brodeur et al. 2002). These depleted carbon values could reflect a food web based on ${ }^{13} \mathrm{C}$-depleted terrestrial carbon sources. Tissue-specific isotopic fractionation has been observed in other organisms (e.g. SholtoDouglas 1991, Schmidt et al. 2004), and the differences in stable isotope ratios between tissues and mesoglea of $P$. camtschatica indicate that tissue-specific isotopic fractionation is occurring in mesoglea, too. This may have implications for trophic studies. Since the mesoglea has a higher water content than other tissues, the values for whole animal homogenates are more greatly influenced by gonads and oral arm tissues than by umbrellar mesoglea. Brodeur et al. (2002) used 'umbrellar tissues' for their analyses of stable isotopes of organisms in the Bering Sea. If gonads and oral arm tissue were proportionally underrepresented in their samples, it could partially explain why the scyphomedusa in their report, Chrysaora melanaster, was positioned at a slightly higher tropic level than its parasitoid amphipods, Hyperia medusarum, Hyperoche medusarum, and Themisto libellula.

The stable isotope values of Hyperia medusarum in Puget Sound are similar to those of hyperiid amphipods in the Bering Sea, but $H$. medusarum in the current report displayed much less variability. The values of $\delta^{13} \mathrm{C}$ for $H$. medusarum are similar to those of Parathemisto pacifica from Washington reported previously (Simenstad \& Wissmar 1985). The values of $\delta^{15} \mathrm{~N}$ for Puget Sound H. medusarum overlap with those of adults of the free-living hyperiid amphipod Themisto japonica from the Sea of Japan (Sugisaki et al. 1991). 
However, the similarities between juvenile and adult amphipods in the present study stand in contrast to $T$. japonica, which shows an ontogenic switch in trophic level from herbivore to carnivore (Sugisaki et al. 1991). The similarity between stable isotope values of hyperiid amphipods may highlight their trophic reliance on gelatinous zooplankton.

\section{Energetics}

There were no differences in metabolic rates or enzymatic activities between free-living megalopae and the epibiotic megalopae. Therefore, megalopae associated with Phacellophora camtschatica are able to devote more energy to development and growth than free-living megalopae in the water column. As the megalopae living in association are capable of collecting food without the energetic cost of swimming, this could shorten the approximate 2 wk duration of the megalopal stage (Ally 1975) and increase survival rates of ectosymbiotic crabs. Cancer gracilis larvae may be more susceptible to some dietary insufficiencies than their congeners in southern Puget Sound (Sulkin \& McKeen 1999), and epibiotic crab larvae may have better access to nutritionally suitable prey than freeliving crab larvae. Sulkin \& McKeen (1994) found that C. gracilis larvae had significantly less mortality and faster development at $15^{\circ} \mathrm{C}$ than at $10^{\circ} \mathrm{C}$. By transporting megalopae and instars into warmer surface waters, medusae may allow crabs to develop faster by increasing their growth rates due to the boost in temperature, while simultaneously reducing the energetic costs associated with locomotion.

To quantify the possible negative impact of Cancer gracilis on Phacellophora camtschatica, the potential energy consumption of megalopae can be related to the energy content of $P$. camtschatica. Pelagia colorata, another surface-dwelling scyphozoan in the same size range as $P$. camtschatica, contains $0.196 \mathrm{~kJ} \mathrm{~g}^{-1}$ wet weight (E. V. Thuesen \& J. J. Childress unpubl. data). Assuming that the energy content of $P$. camtschatica is roughly equivalent, a moderate-sized medusa would contain about $1330 \mathrm{~kJ}$. With a calculated energetic ration of $0.021 \mathrm{~kJ} \mathrm{~g}^{-1} \mathrm{~d}^{-1}$, the average number of megalopae (35) on an individual P. camtschatica in June and July could consume approximately $2.82 \mathrm{~kJ} \mathrm{~d}^{-1}$. This is equivalent to $2 \%$ of the energy content in a typical host over a $10 \mathrm{~d}$ association, not accounting for growth or regeneration in the medusa or diversity in the diet of C. gracilis. Given the rapid increase in the size of $P$. camtschatica over a few months $(1$ to $60 \mathrm{~cm})$, it is unlikely that even large numbers of $C$. gracilis riders have a negative impact on $P$. camtschatica populations.

\section{CONCLUSIONS}

The results of this study suggest that Phacellophora camtschatica concentrates Hyperia medusarum in its oral arms as the symbionts transfer from prey to predator. Larval and juvenile $H$. medusarum are found throughout the winter in local populations of Aurelia labiata, Aequorea victoria and Pleurobrachia bachei, allowing the hyperiid amphipods to overwinter on pelagic hosts. Adult hyperiids are less commonly found in Aurelia labiata, and are absent from Aequorea victoria and $P$. bachei. $P$. camtschatica feeds primarily on these cnidarians, which typically harbor hyperiids in much smaller numbers per medusa. Strand \& Hamner (1988) found that at bell widths of $<18 \mathrm{~cm}$, P. camtschatica are usually unable to capture Aurelia labiata. At larger sizes, the number and size of $A$. labiata captured increases with increasing bell width of $P$. camtschatica, potentially accelerating the accumulation of amphipods. The mean bell width of $P$. camtschatica in this study remained at $<15 \mathrm{~cm}$ until September; it then increased to $>20 \mathrm{~cm}$ in September, and the number of hyperiids concurrently increased approximately 7 -fold. Acquiring only a few parasites from each individual, P. camtschatica could easily accumulate hundreds of amphipods in a season. In this sense, these other coelenterates may constitute intermediate hosts of $H$. medusarum, until the definitive host, $P$. camtschatica, appears in the spring.

The symbiotic association between Cancer gracilis and Phacellophora camtschatica is unusual due to the ontogenic switch of the symbiont from a direct parasite to a cleaning associate. Beginning its association with the scyphomedusa as a megalopa, the crab consumes the tentacles and uses the medusa as a platform to glean small planktonic prey from the water and from the surfaces of the host. As the crab develops through the initial juvenile stages, the instar continues to ingest prey captured by the medusae, but shifts much of its diet to include Hyperia medusarum, thus reducing the overall parasitic impact on the host. However, the high population densities of $H$. medusarum must eventually overwhelm any potential benefit the host gains from C. gracilis instars. P. camtschatica provides not only a physical structure for the megalopal and early juvenile stages of C. gracilis, but also provides protection from predation, serves as an energy-saving transport, and is an abundant source of food. Individuals of $C$. gracilis clearly benefit from their association with $P$. camtschatica, and our behavioral observations and plankton tow data demonstrated that juvenile crabs prefer to exist in symbiosis with the medusa. In order to determine the impact of the symbiosis on C. gracilis populations, further investigations are needed to examine the correlation of $P$. camtschatica outbreaks with the population structure of C. gracilis. 
Acknowledgements. We thank M.T. Biondi for his preliminary work on this project, R. Petty for running the stable isotope analyses at UCSB, and M. A. Gutowska, A. Robbins, P. L. Brommer, L. D. Rutherford, W. Towanda, and R. Fenske for help with sample collection. Boston Harbor Marina graciously allowed us to collect specimens from their docks. Discussions with M. T. Biondi, W. M. Graham and J. M. Orensanz improved our work, and D. Boltovskoy kindly provided space that facilitated the final stages of this project. Comments by W. M. Graham and 2 anonymous referees improved our manuscript. An Evergreen State College Faculty Development Award to E.V.T. and NSF grants OCE-9986680 to E.V.T. and DBI-0215820 to J. Longino, E. Kutter and E.V.T. supported parts of this project.

\section{LITERATURE CITED}

Ally JRR (1975) Description of the laboratory-reared larvae of Cancer gracilis Dana, 1852 (Decapoda, Brachyura). Crustaceana 28:231-246

Arai MN (1988) Interactions of fish and pelagic coelenterates. Can J Zool 66:1913-1927

Ates RML (1991) Predation on Cnidaria by vertebrates other than fishes. Hydrobiologia 216/217:305-307

Bowman TE (1973) Pelagic amphipods of the genus Hyperia and closely related genera (Hyperiidea: Hyperiidae). Smithson Contrib Zool:1-76

Brandon M, Cutress CE (1985) A new Dondice (Opisthobranchia: Favorinidae), predator of Cassiopeia in southwest Puerto Rico. Bull Mar Sci 36:139-144

Brett JR, Groves TD (1979) Physiological energetics. In: Hoar WS, Randall DJ (eds) Fish physiology, Vol VIII. Academic Press, New York, p 279-351

Brodeur RD (1998) In situ observations of the association between juvenile fishes and scyphomedusae in the Bering Sea. Mar Ecol Prog Ser 163:11-20

Brodeur RD, Sugisaki H, Hunt GL (2002) Increases in jellyfish biomass in the Bering Sea: implications for the ecosystem. Mar Ecol Prog Ser 233:89-103

Browne JG, Kingsford MJ (2005) A commensal relationship between the scyphozoan medusae Catostylus mosaicus and the copepod Paramacrochiron maximum. Mar Biol 146:1157-1168

Bruce AJ (1972) An association between a pontoniinid shrimp and a rhizostomatous scyphozoan. Crustaceana 23:300-302

Corrington JD (1927) Commensal association of a spider crab and a medusa. Biol Bull (Woods Hole) 53:346-350

Davenport J (1994) A cleaning association between the oceanic crab Planes minutus and the loggerhead sea turtle Caretta caretta. J Mar Biol Assoc UK 74:735-737

DeBrosse G, Baldinger AJ, McLaughlin PA (1990) A comparative study of the megalopal stages of Cancer oregonensis Dana and C. productus Randall (Decapoda: Brachyura: Cancridae) from the northeastern Pacific. Fish Bull (Wash DC) 88(1):39-49

Dittrich BU (1988) Studies on the life cycle and reproduction of the parasitic amphipod Hyperia galba in the North Sea. Helgol Meeresunters 42:79-98

Frick MG, Williams KL, Veljacic D (2000) Additional evidence supporting a cleaning association between epibiotic crabs and sea turtles: how will the harvest of Sargassum seaweed impact this relationship? Mar Turtle Newsl 90:11-13

Frick MG, Williams KL, Veljacic D (2002) New records of epibionts from loggerhead sea turtles Caretta caretta (L.). Bull Mar Sci 70:953-956
Garth JS, Abbott DP (1980) Brachyura: the true crabs. In: Morris RH, Abbott DP, Haderlie EC (eds) Intertidal invertebrates of California. Stanford University Press, Stanford, CA, p 594-630

Gasca R, Haddock SHD (2004) Associations between gelatinous zooplankton and hyperiid amphipods (Crustacea: Peracarida) in the Gulf of California. Hydrobiologia 530/531:529-535

Graham WM (1994) The physical oceanography and ecology of upwelling shadows. Doctoral dissertation (PhD), University of California, Santa Cruz, CA

Gutsell JS (1928) The spider crab, Libinia dubia, and the jellyfish Stomolophus meleagris, found associated at Beaufort, North Carolina. Ecology 9:358-359

Harbison GR, Biggs DC, Madin LP (1977) The association of Amphipoda Hyperiidae with gelatinous zooplankton. II. Associations with Cnidaria, Ctenophora and Radiolaria. Deep-Sea Res 24:465-488

Harrison NM (1984) Predation on jellyfish and their associates by seabirds. Limnol Oceanogr 29:1335-1337

Heeger T (1998) Quallen. Wissenschaftliche Verlagsgesellschaft, Stuttgart

Hinz S, Sulkin S, Strom S, Testerman J (2001) Discrimination in ingestion of protistan prey by larval crabs. Mar Ecol Prog Ser 222:155-162

Hyman LH (1940) The invertebrates: Protozoa through Ctenophora, Vol 1. McGraw-Hill, New York

Jachowski R (1963) Observations on the moon jelly, Aurelia aurita, and the spider crab Libinia dubia. Chesapeake Sci $4: 195$

Jones S (1960) Notes on animal associations 2. The Scyphomedusa, Acromitus flagellatus Stiasny and young Seleroides leptolepis (Cuvier \& Valenciennes) with the latter forming a vanguard. J Mar Biol Assoc India 2:51-52

Larson RJ (1990) Scyphomedusae and cubomedusae from the eastern Pacific. Bull Mar Sci 47:546-556

Laval P (1980) Hyperiid amphipods as crustacean parasitoids associated with gelatinous zooplankton. Oceanogr Mar Biol Annu Rev 18:11-56

Libes SM (1992) An introduction to marine biogeochemistry. Wiley, New York

Madin LP, Harbison GR (1977) The associations of Amphipoda Hyperiidae with gelatinous zooplankton. I. Associations with Salpidae. Deep-Sea Res 24:449-463

Malej A, Faganeli J, Pezdič J (1993) Stable isotope and biochemical fractionation in the marine pelagic food chain: the jellyfish Pelagia noctiluca and net zooplankton. Mar Biol 116:565-570

Marliave JB, Mills CE (1993) Piggyback riding by pandalid shrimp larvae on hydromedusae. Can J Zool 71:257-263

Martin JW, Kuck HG (1991) Faunal associates of an undescribed species of Chrysaora (Cnidaria, Scyphozoa) in the Southern California Bight, with notes on unusual occurrences of other warm water species in the area. Bull South Calif Acad Sci 90:89-101

Montoya JP, Horrigan SG, McCarthy JJ (1990) Natural abundance of ${ }^{15} \mathrm{~N}$ in particulate nitrogen and zooplankton in the Chesapeake Bay. Mar Ecol Prog Ser 65:35-61

Morton B (1989) Partnerships in the sea. Hong Kong University Press, Hong Kong

Noble A (1963) On the association between the fish, Caranx malabaricus Cuv. \& Va. and the siphonophore Porpita pacifica Lesson. J Mar Biol Assoc India 5:142-143

Orensanz JM, Gallucci VF (1988) Comparative study of postlarval life-history schedules in four sympatric species of Cancer (Decapoda: Brachyura: Cancridae). J Crustac Biol $8: 187-220$ 
Orensanz JM, Parma AM, Armstrong DA, Armstrong J, Wardrup P (1995) The breeding ecology of Cancer gracilis (Crustacea, Decapoda, Cancridae) and the mating systems of cancrid crabs. J Zool 235:411-437

Page HM (1997) Importance of vascular plant and algal production to macro-invertebrate consumers in a southern California salt marsh. Estuar Coast Shelf Sci 45:823-834

Pagès F (2000) Biological associations between barnacles and jellyfish with emphasis on the ectoparasitism of Alepas pacifica (Lepadomorpha) on Diplulmaris malayensis (Scyphozoa). J Nat Hist 34:2045-2056

Panikkar NK, Prasad RR (1952) On an interesting association of ophiuroids, fish and crab with the jellyfish Rhopilema hispidum. J Bombay Nat Hist Soc 51:295-296

Peterson BJ, Fry B (1987) Stable isotopes in ecosystem studies. Annu Rev Ecol Syst 18:293-320

Phillips PJ, Burke WD, Keener EJ (1969) Observations on the trophic significance of jellyfishes in Mississippi Sound with quantitative data on the associative behaviour of small fishes with medusae. Trans Am Fish Soc 98:703-712

Purcell JE (1990) Soft-bodied zooplankton predators and competitors of larval herring (Clupea harengus pallasi) at herring spawning grounds in British Columbia. Can J Fish Aquat Sci 47:505-515

Rutherford LD, Thuesen EV (2005) Metabolic performance and survival of medusae in estuarine hypoxia. Mar Ecol Prog Ser 194:189-200

Schimmelmann A, DeNiro MJ (1986) Stable isotopic studies on chitin. II. The ${ }^{13} \mathrm{C} /{ }^{12} \mathrm{C}$ and ${ }^{15} \mathrm{~N} /{ }^{14} \mathrm{~N}$ ratios in arthropod chitin. Contrib Mar Sci 29:113-130

Schmidt K, McClelland JW, Mente E, Montoya JP, Atkinson A, Voss M (2004) Trophic-level interpretation based on $\delta 15 \mathrm{~N}$ values: implications of tissue-specific fractionation and amino acid composition. Mar Ecol Prog Ser 266:43-58

Shanks AL, Graham WM (1988) Chemical defense in a scyphomedusa. Mar Ecol Prog Ser 45:81-86

Sholto-Douglas AD, Field JG, James AG, van der Merwe NJ (1991) ${ }^{13} \mathrm{C} /{ }^{12} \mathrm{C}$ and ${ }^{15} \mathrm{~N} /{ }^{14} \mathrm{~N}$ isotope rations in the Southern Benguela ecosystem: indicators of food web relationships among different size-classes of plankton and pelagic fish; differences between fish muscle and bone collagen tissues. Mar Ecol Prog Ser 78:23-31

Simenstad CA, Wissmar RC (1985) $\delta^{13} \mathrm{C}$ evidence of the origins and fates of organic carbon in estuarine and nearshore food webs. Mar Ecol Prog Ser 22:141-152

Sorarrain DR, Ramirez F, Mianzan H (2001) Hyperoche medusarum (Krøyer, 1838) (Amphipoda, Hyperiidae) and Mnemiopsis mccradyi (Mayer, 1910) (Ctenophora): a new host and first record of this association for the southwestern Atlantic. Crustaceana 74:407-410

Strand SW, Hamner WM (1988) Predatory behaviour of Phacellophora camtschatica and size-selective predation upon Aurelia aurita (Scyphozoa: Cnidaria) in Saanich Inlet, British Columbia. Mar Biol 99:409-414

Editorial responsibility: Jennifer E. Purcell (Contributing Editor), Anacortes, Washington, USA
Sugisaki H, Terazaki M, Wada E, Nemoto T (1991) Feeding habits of a pelagic amphipod, Themisto japonica. Mar Biol 109:241-244

Sulkin SD, McKeen G (1994) Influence of temperature on larval development of four co-occurring species of the brachyuran genus Cancer. Mar Biol 118:593-600

Sulkin SD, McKeen G (1999) The significance of feeding history on the value of heterotrophic microzooplankton as prey for larval crabs. Mar Ecol Prog Ser 186:219-225

Suzuki K (1965) On a young crab found near the oral arms of the jellyfish Rhopilema esculenta Kishinouye. Res Crustac (Kokurui no Kenkyu) 2:77-82

Thiel ME (1970) Das Zusammenleben von Jung- und Kleinfischen mit Rhizostomeen (Scyphomedusae). Ber Dtsch Wiss Komm Meeresforsch 21:444-473

Thiel ME (1976) Wirbellose Meerestiere als Parasiten, Kommensalen oder Symbionten in oder an Scyphomedusen. Helgol Meeresunters 28:417-446

Thiel M, Baeza JA (2001) Factors affecting the social behaviour of crustaceans living symbiotically with other marine invertebrates: a modeling approach. Symbiosis 30:163-190

Théodoridès J (1989) Parasitology of marine zooplankton. Adv Mar Biol 25:117-165

Thuesen EV, Childress JJ (1994) Oxygen consumption rates and metabolic enzyme activities of oceanic California medusae in relation to body size and habitat depth. Biol Bull (Woods Hole) 187:84-98

Thuesen EV, Rutherford LD, Brommer PL, Garrison K, Gutowska MA, Towanda T (2005) Intragel oxygen promotes hypoxia tolerance of scyphomedusae. J Exp Biol 208:2475-2482

Thurston MH (1977) Depth distributions of Hyperia spinigera Bovallius, 1889 (Crustacea: Amphipoda) and medusae in the North Atlantic Ocean, with notes on the associations between Hyperia and coelenterates. In: Angel MV (ed) A voyage of discovery. George Deacon 70th anniversary volume. Pergamon Press, Oxford, p 499-536

Trott LB (1972) The portunid crab Charybdis feriatus (Linnaeus) commensal with the scyphozoan jellyfish Stomolophus nomurai (Kishinouye) in Hong Kong. Crustaceana 23:305-306

Wahl M, Olaf M (1999) The predominantly facultative nature of epibiosis: experimental and observational evidence. Mar Ecol Prog Ser 187:59-66

Weymouth FW (1910) Synopsis of the true crabs (Brachyura) of Monterey Bay California, Vol 4. Stanford University, CA

Wickham DE (1979) The relationship between megalopae of the Dungeness crab, Cancer magister, and the hydroid, Velella velella, and its influence on abundance estimates of C. magister megalopae. Bull Dep Fish Game St Calif 65: 184-186

Wrobel D, Mills CE (1998) Pacific coast pelagic invertebrates. Sea Challengers, Monterey, CA

Submitted: May 5, 2005; Accepted: November 16, 2005

Proofs received from author(s): May 31, 2006 